\title{
Knowledge Synthesis in Health, Wellness and Social Care Research: The Fundamentals of Conducting Comprehensive Reviews
}

\author{
Mashrur Rahman Kazi1, Nashit Chowdhury¹, Mohammad M. Z. I. Chowdhury1, Tanvir C. Turin'1,2*
}

1 Department of Family Medicine,

University of Calgary, Alberta, Canada

2 Department of Community Health Sciences,

University of Calgary, Alberta, Canada

*Corresponding author's email:

turin.chowdhury@ucalgary.ca

Received: 24 June 2021

Accepted: 9 September 2021

DOI: https://doi.org/10.51200/bjms.vi.3209

Keywords: knowledge synthesis,

review typology, steps of review,

systematic review, review

methodology

\section{ABSTRACT}

Knowledge synthesis is often a term that is widely used to define the process of summarizing and integrating research findings into the existing field of research of a specific topic. While knowledge syntheses can take many forms, it is commonly produced as a review of previously published literature in a specific field. With the recent tremendous increase in scientific, especially health, publications, conducting literature reviews has become an absolute necessity for investigators to scope out the body of research work that has already been done. Literature reviews provide a unique function of providing a clear and articulate understanding of the extent of previous work that has been done such that resources are not wasted in redundant duplication. Moreover, literature reviews can serve multiple purposes such as providing context to current crises, efficiently summarizing previously published work, identifying gaps in the literature of a specific topic, and aiding the overall advancement of knowledge in the research field of interest. In this manuscript, we provide detailed general steps for conducting a review based on standard and common methodological frameworks used to inform and conduct knowledge syntheses.

\section{INTRODUCTION}

Knowledge synthesis is often a term that is widely used to define the process of summarizing and integrating research findings into the existing field of research of a specific topic (Grimshaw, 2010). They are generally done to contextualize research findings within the global evidence of research done, thus 
providing investigators with what has been done and what still needs to be investigated. These knowledge syntheses can be conducted by gathering information on a specific topic from different sources of information (original research, previously published research, grey literature, academic publications, etc.) (Kastner et al., 2012).

While knowledge syntheses can take many forms, it is commonly produced as a review of previously published literature in a specific field (Grimshaw, 2010). Synthesis of previously published literature can be presented in a wide range of ways such as systematic reviews, scoping reviews, rapid reviews, meta-analyses, meta-syntheses, etc. Such reviews allow the researchers to be up to date with the current research landscape and to identify the gaps in the current literature so new research can be initiated to address these gaps.

With the recent tremendous increase in scientific, especially health, publications, conducting literature reviews has become an absolute necessity for investigators to scope out the body of research work that has already been done. Literature reviews provide a unique function of providing a clear and articulate understanding of the extent of previous work that has been done such that resources are not wasted in redundant duplication (Samnani et al., 2017). Moreover, literature reviews can serve multiple purposes such as providing context to current crises, efficiently summarizing previously published work, identifying gaps in the literature of a specific topic, and aiding the overall advancement of knowledge in the research field of interest.

\section{General Steps to Conducting a Review}

In this manuscript, we will provide detailed general steps to conducting a review based on standard and common methodological frameworks used to inform and conduct knowledge syntheses (Ahmed et al., 2016; Samnani et al., 2017). These steps provide general guidance for anyone conducting a literature review. Figure 1 outlines the steps of conducting a review.

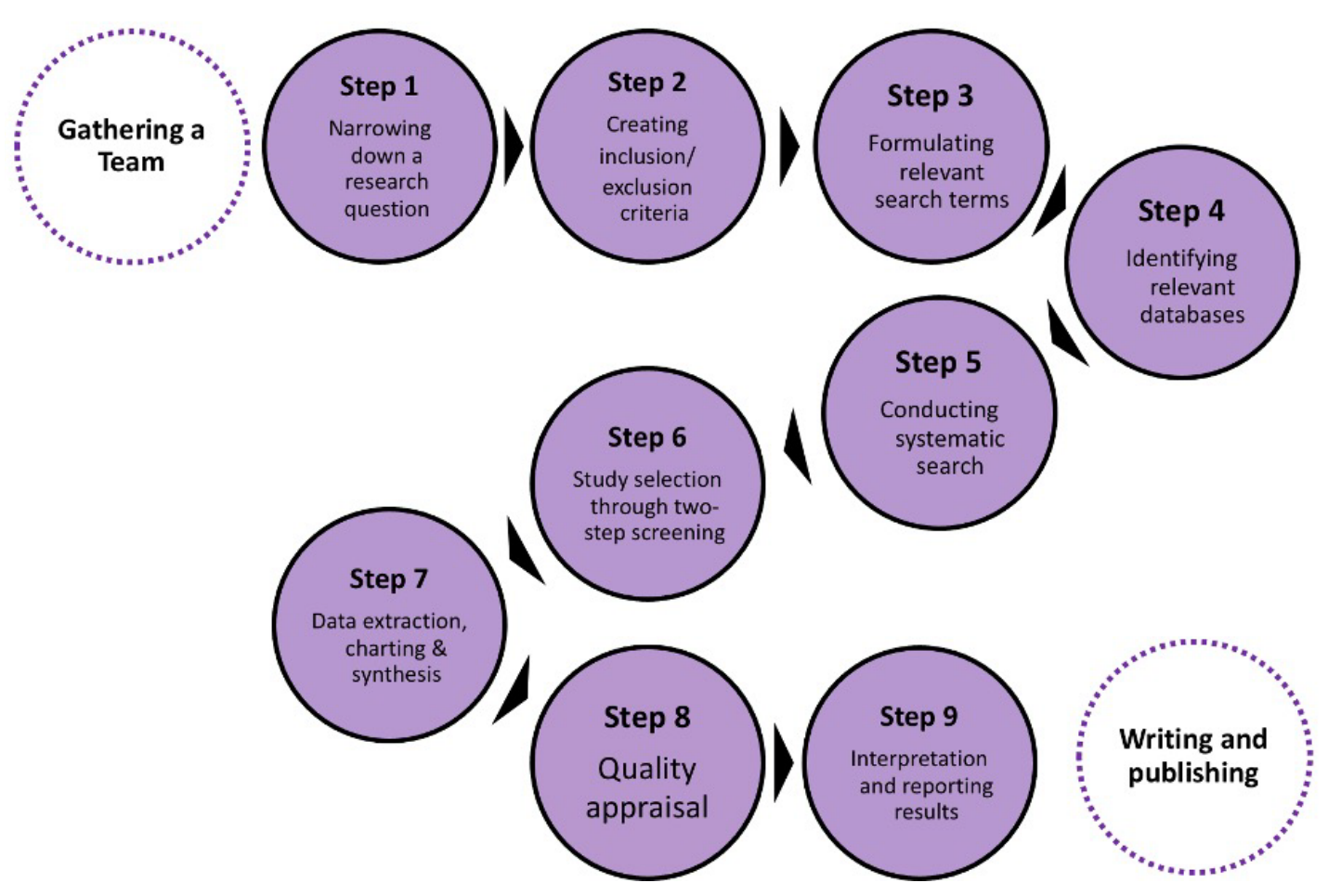

Figure 1 General steps of conducting a review 


\section{Step 1: Focusing on a research question}

To conduct a review, investigators need to develop a research question first that is reflective of the objectives, scope, and specific inquiries of the review. The research question and objectives of the review will ultimately shape the inclusion/exclusion criteria, therefore, dictate the capture of information done through knowledge synthesis. There are a few established frameworks that can be used to inform and formulate the research question. The PICOS framework is one of such frameworks that is often used by researchers to recognize the scope of the research question (Schardt et al., 2007). PICOS stands for Population, Interventions, Comparison, Outcome, and Study design. The PICOS are generated based on the research question.

\section{Step 2: Creating exclusion/ inclusion criteria}

Following the formulation of the research question, investigators may develop inclusion/ exclusion criteria, which will determine how comprehensive or specific the knowledge synthesis will be (Ahmed et al., 2016). A welldefined inclusion/exclusion criterion will inform the researchers and readers about the breadth and depth (scope) of the review article (Lockwood et al., 2019). The inclusion/exclusion criteria act as a guide for the investigators as it informs them which information to accept into the review and which information to reject. Firm reasoning and justification can be provided behind each inclusion/exclusion criterion to make the study approach clearer for the readers (Tricco et al., 2018). Further, the timeline of the research and the languages included in the review are stated at this stage (Ahmed et al., 2016).

\section{Step 3: Formulating relevant search terms}

To find the studies that have been done before, researchers need to identify a set of relevant keywords to be used in a systematic search. Given its essential nature, formulating relevant keywords is a crucial step as it yields the articles relevant to the context of the synthesis (Ahmed et al., 2016). To formulate optimized keywords, investigators initially perform a limited search on the topic of interest. This initial search serves the function of informing the investigators about relevant keywords as they can scan the title and abstract of relevant literature for them (University of Tasmania, 2021). The limited search also helps shape the scope of the review further as the researchers can recognize the keywords that are specific to the topic and will yield the most optimized results (yielding of most relevant articles from a systematic search of databases) (Ahmed et al., 2016). Furthermore, this search allows the investigators to have a look at relevant search databases as well, therefore allowing the investigators to recalibrate and optimize their entire search strategy for desired results (Chowdhury \& Turin, 2019).

It should be noted that search terms are often dichotomously categorized into Medical Subject Heading (MeSH) and keywords. Medical Subject Headings or MeSH terms are keywords that have been created and used by the National Library of Medicine to categorize and archive information/literature relating to medicine and health (U.S. National Library of Medicine, 2012). As these terms have been used by other researchers who have published works, they are quite useful in yielding relevant articles when included in the search strategy for the systematic search. Keywords are more straightforward in their definition; in that, they are phrases or words that can be utilized for searching a database. To come up with the most relevant keywords for the search, investigators may want to break down the main research question, each section of the PICOS, and the purpose of the review into fragmented parts. After this division, the investigators can formulate relevant keywords for each specific component, which can then be combined for the systematic search to yield the most relevant literature. 
Step 4: Identifying relevant search databases

\section{(a) Academic Data Sources}

Once the keywords have been created and finalized by the investigators, relevant search databases need to be identified for a systematic search (Ahmed et al., 2016). Most electronic search databases are specific to the topic of interest, and therefore the researchers try to identify and evaluate how relevant the database is to their topic of interest (Lefebvre $C$ et al., 2019). As mentioned in the previous step, a limited search can inform the investigators about relevant search databases that will yield the most optimized results for the knowledge synthesis. In parallel with the keywords, relevant databases are also informed by the primary research question. For example, for a very clinical question, we will need to make sure that we include the databases which were predominantly a source for clinical studies (Bramer et al., 2018). On the other hand, a review study focusing on the social determinants of health issues needs to include all the broader health and wellness research databases. To find the most relevant articles, it is recommended that the investigators search as many relevant databases as possible as it would exhaustively address the primary research question, ensuring a lower chance of missed relevant articles (Ahmed et al., 2016). It should be noted that this process will often produce large quantities of duplicate articles. However, these duplicates can be easily removed by appropriate referencing software. Table 1 presents different academic literature databases which are conventionally used for conducting reviews for health research.

Table 1 A sample list of databases to be searched to identify literature for this synthesis

\begin{tabular}{|c|c|}
\hline Published articles & Grey literature \\
\hline 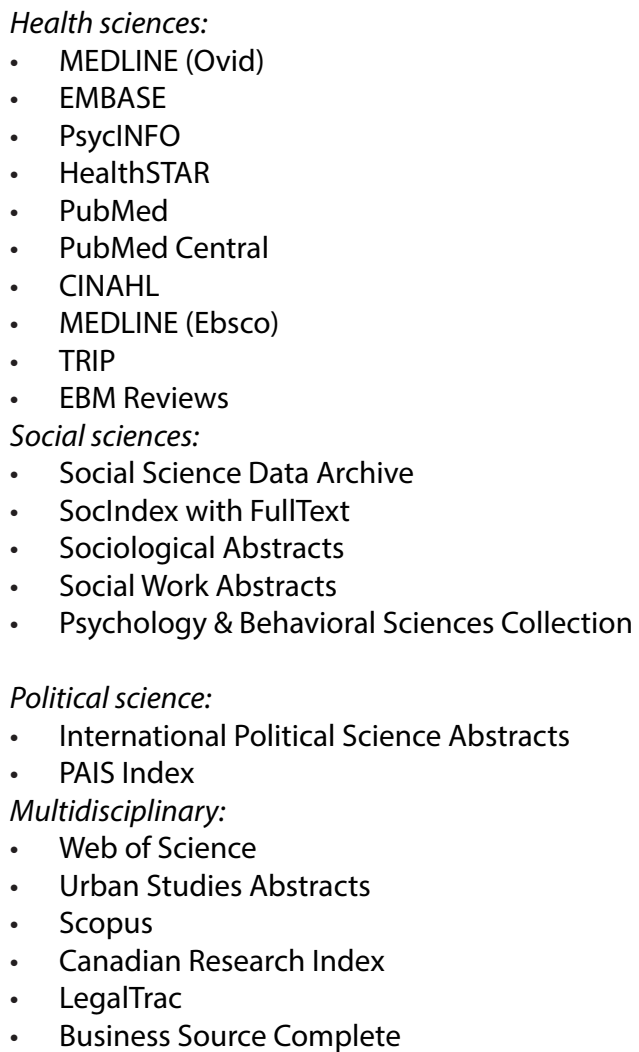 & $\begin{array}{l}\text { Academic-focused search engines: } \\
\text { - Google Scholar } \\
\text { Repositories/theses: } \\
\text { - } \quad \text { ProQuest (theses and dissertations) } \\
\text { - OAISter (WorldCat) } \\
\text { Health sciences: } \\
\text { - Health Sciences Online (HSO) } \\
\text { - Turning Research into Practice (TRIP) } \\
\text { - Canadian Institutes of Health Research (CIHR) } \\
\text { - Canadian Institute for Health Information (CIHI) } \\
\text { - Public Health Agency of Canada (PHAC) } \\
\text { - Health Canada } \\
\text { - National Institutes of Health (NIH) } \\
\text { - World Health Organization (WHO) } \\
\text { - } \quad \text { Alberta Health Services (AHS) Insite } \\
\text { Social sciences: } \\
\text { - Federation of Data Organizations for Social Science (IFDO) } \\
\text { - Consortium of Social Science Associations (COSSA) } \\
\text { - Organization for Social Science Research in Eastern and } \\
\text { - Southern Africa (OSSREA) } \\
\text { International Organization of Social Sciences and } \\
\text { - Behavioral Research (IOSSBR) } \\
\text { - } \text { (IFSSO) }\end{array}$ \\
\hline
\end{tabular}




\section{(b) Grey Literature Data Sources}

In congruence with academic databases, the investigators also search for the grey literature sources to understand the complete scope of their extensive systematic search. Due to the rapid nature of information production in today's world, grey literature has become an essential part of knowledge synthesis to understand the global evidence regarding the topic of interest. Grey literature is defined as rapid and non-conventional sources of information that include a variety of different documents and sources of information such as government documents, websites, blogs, etc. (Schöpfel \& Farace, 2010). Google and Google scholar are search engines that are often used for searching grey literature, given the expansive collection of information that exists within these search engines (Vaska et al., 2019). Just like academic databases, grey literature databases are also specific to the topic and should be identified accordingly. Table 1 presents several grey literature databases or repositories that are commonly used for conducting reviews in health and social science-related research topics. Figure 2 shows a larger number of potential grey literature sources.

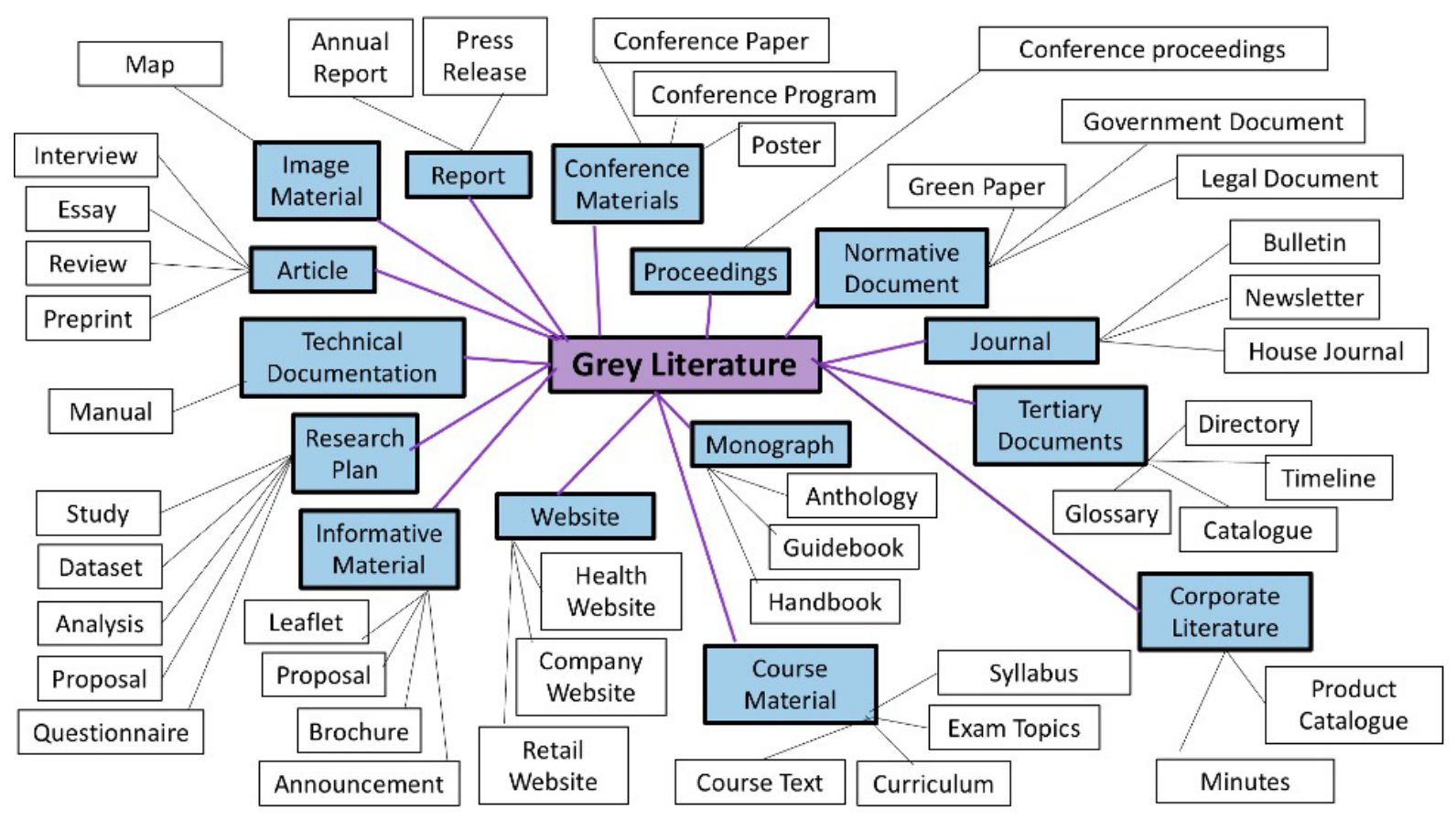

Figure 2 Grey literature typology

\section{Step 5: Conducting a systematic search}

After finalizing the relevant keywords and databases, we conduct a systematic search (Ahmed et al., 2016). To do so, a search strategy needs to be created by the investigators. Much like the previous two steps, the search strategy needs to be reflective of the primary research question. This is done by creating a comprehensive and specific search strategy that reflects the objectives of the review and is robust enough to capture the most relevant articles to the research question (Ahmed et al., 2016). Search strategies are specific to databases and may need to be adjusted (different keywords and headings) accordingly to capture all relevant articles from each database (Bramer et al., 2018). Creating a search strategy is often done by the use of Boolean operators "OR" and "AND" to combine the keywords and MeSH terms generated in the previous steps. First, the search terms within each 
component of the research question (informed by the PICOS framework) are combined using the "OR" function to provide a wide scope of capture (Methley et al., 2014). The results from this stage are then further combined using the "AND" function to execute an exhaustive systematic search that is reflective of the research question in its entirety.

As the grey literature realm is quite rapid and expansive in its manner of knowledge production, grey literature database searching is focused primarily on using keywords to perform the systematic search (Vaska et al., 2019). Much like academic databases, keywords from within each component of the research question are combined by using Boolean operators "OR" and then these results are combined with the Boolean operator "AND". These keywords are then used to search Google Scholar and Google, as these act as the fundamental search databases for capturing information from grey literature. Due to the algorithm that dictates the relevancy of information, this search is often limited to the first 100 results or 10 pages (Canadian Agency for Drugs and Technologies in Health [CADTH], 2018).

\section{Step 6: Study selection through a two-step screening}

To conduct reviews, the investigators need to be able to identify relevant articles from the vast body of information that will not be relevant to the purpose of the knowledge synthesis. To screen out irrelevant information, investigators perform a two-step screening as it allows them to proceed with only the most relevant information for the review. This process has two phases: title and abstract screening and full-text screening.

\section{(a) Title-Abstract Screening}

During the title and abstract screening phase, generally, two independent investigators commence the screening at the same time (Tricco et al., 2018). They screen the abstract and title of every article that has been yielded through the systematic search. As the investigators independently comb through the title and abstract of each article, they scrutinize if the information presented meets the established inclusion criteria. If an article does meet all the requirements, it can then be graduated to the second phase (full-text screening). If the information presented in the title and abstract of the yielded literature is deemed to be inconclusive, thus creating doubt, then it can be modified to be included for the full-text screening phase (Lockwood et al., 2019).

\section{(B) Full-Text Screening}

Once all the titles and abstracts have been thoroughly screened, the investigators move on to the full-text screening phase. This stage consists of the investigators reading the entire text of each article that was included in the first stage. A full read of the articles will inform the investigators undoubtedly about their decision to either include or exclude the article from the review. If disagreements arise between the decisions for inclusion made by the individual investigators, then both investigators collaborate and use the inclusion criteria to decide on the article in question. At the full-text screening phase, the final decision to either accept or reject articles for the review is made. Investigators can also employ other methods such as Pearl Growing, Snowballing, or Citation Mining (Icahn School of Medicine at Mount Sinai, 2020), where the references of selected articles are thoroughly scanned to find other potentially missed papers. As this process is thorough, software such as Covidence, MS Excel, EndNote, and RefWorks are often utilized to facilitate the process.

Step 7: Data extraction, charting, and synthesis

After finalizing the study selection stage, the information presented within these studies is extracted and organized appropriately. About presenting the information, reviews provide a 
high degree of freedom for the investigators to do so as they see fit for the knowledge synthesis (Samnani et al., 2017). It is important to keep in mind that information should be presented in a way that is coherent, logical, and easy to follow for the readers (Tricco et al., 2018). Information can be presented in the form of tables, charts, figures, or diagrams. The information that is extracted and presented needs to be aligned with and reflective of the primary purpose of the knowledge synthesis (Ahmed et al., 2016). As mentioned earlier, there is a multitude of different ways to present information that has been extracted from selected articles. However, in general, the first table of the review describes the studies that were included in the knowledge synthesis. Information such as year of publication, demographic information, author, place of research, research methods, etc., can be listed here. The following tables and figures are completely at the discretion of the investigators and their choices of presenting the findings in a way that reflects the overarching objective of the review.

\section{Step 8: Study quality appraisal}

An important step of the knowledge synthesis is the appraisal of the quality of the sources of evidence. However, it is not mandatory for all reviews but strongly recommended for certain types of reviews that entail a deeper level of syntheses such as a systematic review and meta-analysis. To evaluate the sources that are eligible for the final level of the synthesis, a predetermined set of criteria is used. Generally, the criteria include various characteristics of the articles such as objective, methods, interventions, etc. Differently structured checklists are available that can be used for a quality appraisal (Shepherd et al., 2013). However, the appropriate quality appraisal tools/checklists need to be employed according to the type of the study (e.g., quantitative or qualitative) (Chowdhury \& Turin, 2019).

\section{Step 9: Interpretation and reporting results}

Investigators now need to summarize the extracted information from the research articles and present it coherently and logically such that it is aligned with the research question being investigated in the knowledge synthesis (Samnani et al., 2017). By this stage of the process, the information has been extracted and charted and therefore it can be organized and summarized at the discretion of the investigators (Lockwood et al., 2019). Often, themes can be found within the extracted information, leading to the thematic categorization of this information being presented in the review (McKenzie \& Brennan, n.d.). This categorization should reflect the aims of the research question and so it is fully dependent on the results that were yielded from the articles included in the review. At this stage, investigators should also state the gaps that exist in the literature as this gives readers an understanding of the research landscape and inform them about future research that needs to be done.

\section{Different Types of Reviews}

\section{Review Typology}

There are different types of reviews. The choice of which type of review to conduct is often governed by the purpose of the study and the breadth and depth of information synthesis. The specific characteristics associated with the different types of reviews are provided in Table 2. Table 3 describes the major features of different types of reviews based on the Search, Appraisal, Synthesis, and Analysis (SALSA) analytical framework (Grant \& Booth, 2009). 
Table 2 Characteristics of common types of reviews

\begin{tabular}{|c|c|c|c|}
\hline Type of Review & Key Attributes & Strengths & Deficiencies \\
\hline $\begin{array}{l}\text { Literature Review / } \\
\text { Narrative Review / } \\
\text { Overview Review }\end{array}$ & $\begin{array}{l}\text { Evaluate the current literature } \\
\text { on a particular topic } \\
\text { - Need specific inclusion criteria } \\
\text { for selecting studies }\end{array}$ & $\begin{array}{l}\text { - Consolidate previously } \\
\text { known knowledge } \\
\text { - Comparatively quick to } \\
\text { perform }\end{array}$ & $\begin{array}{l}\text { Does not emphasize analyzing } \\
\text { collected data } \\
\text { Does not require a formal } \\
\text { systematic search, thus } \\
\text { generating the possibility of } \\
\text { bias by omitting or limiting a } \\
\text { search }\end{array}$ \\
\hline Scoping Review & $\begin{array}{l}\text { Evaluate the potential scope } \\
\text { of literature available on a } \\
\text { particular topic } \\
\text { Identify the extent of resources } \\
\text { available, including ongoing } \\
\text { research }\end{array}$ & $\begin{array}{l}\text { - Identify the need for } \\
\text { full systematic review } \\
\text { - Identify gaps in the } \\
\text { literature for future } \\
\text { research } \\
\text { - Update researchers, } \\
\text { policymakers about } \\
\text { the extent of work } \\
\text { already done }\end{array}$ & $\begin{array}{l}\text { Lack of quality assessment risks } \\
\text { the inclusion of studies based } \\
\text { on their existence rather than } \\
\text { their intrinsic quality }\end{array}$ \\
\hline Integrative Review & $\begin{array}{l}\text { Encompasses the } \\
\text { broadest ranging research } \\
\text { methodologies to capture } \\
\text { information from both non- } \\
\text { experimental and experimental } \\
\text { data } \\
\text { - Utilizes both empirical and } \\
\text { theoretical information }\end{array}$ & $\begin{array}{l}\text { - Inclusion of a diverse } \\
\text { set of methodologies } \\
\text { - This can lead to theory } \\
\text { development } \\
\text { - Direct application to } \\
\text { policy and practice }\end{array}$ & $\begin{array}{l}\text { The incorporation of diverse } \\
\text { methodologies can lead to } \\
\text { inaccuracy and bias in the } \\
\text { review } \\
\text { - Combining empirical and } \\
\text { theoretical data can potentially } \\
\text { lead to complicacy }\end{array}$ \\
\hline Critical Review & $\begin{array}{l}\text { - Critically evaluate effectiveness } \\
\text { and quality of cited resources } \\
\text { - A reader can make a } \\
\text { judgement about the topic of } \\
\text { interest }\end{array}$ & $\begin{array}{l}\text { - Extract information } \\
\text { critically } \\
\text { - Quick and elaborated } \\
\text { overview } \\
\text { - Often involves } \\
\text { competing schools of } \\
\text { thought }\end{array}$ & $\begin{array}{l}\text { - Lack of systematic search } \\
\text { - No formal quality assessment } \\
\text { - Review is subjective and } \\
\text { depends on the authors' } \\
\text { expertise }\end{array}$ \\
\hline Systematic Review & $\begin{array}{l}\text { - Includes systematic approach } \\
\text { for searching literature } \\
\text { following a standard scientific } \\
\text { protocol } \\
\text { - Prime importance in evidence- } \\
\text { based research } \\
\text { - Identify reliable and quality } \\
\text { data }\end{array}$ & $\begin{array}{l}\text { - Gather and assess } \\
\text { the quality of all the } \\
\text { scientific knowledge } \\
\text { on a particular topic } \\
\text { - Reduces bias because } \\
\text { of its systematic nature }\end{array}$ & $\begin{array}{l}\text { Dependent on the quality of } \\
\text { the selected studies. }\end{array}$ \\
\hline Meta-Analysis & $\begin{array}{l}\text { - Develop precise statistical } \\
\text { outcomes of multiple } \\
\text { quantitative studies } \\
\text { - A reader can get an idea about } \\
\text { population characteristics and } \\
\text { results } \\
\text { - Requires all included studies } \\
\text { to have sufficiently similar } \\
\text { measures }\end{array}$ & $\begin{array}{l}\text { - Assimilation of } \\
\text { conclusive and } \\
\text { statistically significant } \\
\text { studies create a solid } \\
\text { evidence base for } \\
\text { practice } \\
\text { - Overcomes the issue of } \\
\text { the small sample size } \\
\text { of individual studies } \\
\text { - Increases precision of } \\
\text { estimating effects }\end{array}$ & $\begin{array}{l}\text { The inappropriateness of } \\
\text { combining studies not similar } \\
\text { enough weakens the finding }\end{array}$ \\
\hline
\end{tabular}




\begin{tabular}{|c|c|c|c|}
\hline Mapping Review & $\begin{array}{l}\text { - Map out and classify existing } \\
\text { literature on a topic } \\
\text { - Differs from scoping review, } \\
\text { as the outcome is not known } \\
\text { beforehand, and the findings of } \\
\text { these reviews will open doors } \\
\text { to further analysis }\end{array}$ & $\begin{array}{l}\text { - Enables } \\
\text { contextualization of } \\
\text { detailed literature } \\
\text { - Important for } \\
\text { policymakers or } \\
\text { decision-makers to } \\
\text { deal with practice- } \\
\text { relevant review } \\
\text { questions } \\
\text { - Also determines } \\
\text { population } \\
\text { characteristics }\end{array}$ & $\begin{array}{l}\text { - Time constrained and lacks a } \\
\text { systematic approach } \\
\text { - May oversimplify or mask the } \\
\text { significant points } \\
\text { - No quality assessment of cited } \\
\text { resources }\end{array}$ \\
\hline $\begin{array}{l}\text { Qualitative } \\
\text { Systematic Review }\end{array}$ & $\begin{array}{l}\text { - Integrate and compare the } \\
\text { outcome of qualitative studies } \\
\text { - Interpret the findings in a } \\
\text { broader aspect on a particular } \\
\text { subject }\end{array}$ & $\begin{array}{l}\text { - Compliments } \\
\text { quantitative research } \\
\text { evidence } \\
\text { - Being generalized } \\
\text { increases its worth } \\
\text { compared to local } \\
\text { surveys }\end{array}$ & - No specific methodology \\
\hline Meta-Synthesis & $\begin{array}{l}\text { - Describe, interpret and } \\
\text { transform data from multiple } \\
\text { qualitative studies } \\
\text { - Aims to determine the } \\
\text { explanation for particular } \\
\text { phenomena as opposed to a } \\
\text { meta-analysis that focuses on } \\
\text { quantitative outcomes }\end{array}$ & $\begin{array}{l}\text { - Involves a rigorous and } \\
\text { systematic approach } \\
\text { - Identifies common } \\
\text { core elements and } \\
\text { themes } \\
\text { - Non-statistical } \\
\text { technique }\end{array}$ & $\begin{array}{l}\text { - Including irrelevant studies will } \\
\text { decrease the effectiveness of } \\
\text { the review } \\
\text { - Studies without a clear } \\
\text { description of each step of } \\
\text { review will not be quickly } \\
\text { adopted for EBM }\end{array}$ \\
\hline Realist Review & $\begin{array}{l}\text { - Deals with finding outcomes } \\
\text { related to complex } \\
\text { interventions } \\
\text { - Aims to seek explanatory focus }\end{array}$ & $\begin{array}{l}\text { - Includes relevant } \\
\text { studies because } \\
\text { of its systematic } \\
\text { methodology } \\
\text { - Explains the outcomes } \\
\text { of findings rather than } \\
\text { judging results }\end{array}$ & $\begin{array}{l}\text { - Uses argumentation analysis to } \\
\text { deal with identifying context } \\
\text { and mechanism of the study } \\
\text { - Complicated and time- } \\
\text { consuming for reviewers }\end{array}$ \\
\hline $\begin{array}{l}\text { Review of reviews/ } \\
\text { Umbrella Reviews }\end{array}$ & $\begin{array}{l}\text { - Extracting outcomes from } \\
\text { multiple reviews }\end{array}$ & $\begin{array}{l}\text { Easier for a reviewer } \\
\text { to go through a single } \\
\text { review } \\
\text { - Helpful for decision- } \\
\text { makers }\end{array}$ & $\begin{array}{l}\text { Requires pre-existence of } \\
\text { the narrowest component of } \\
\text { reviews }\end{array}$ \\
\hline $\begin{array}{l}\text { Mixed Methods } \\
\text { Review / Mixed } \\
\text { Studies Review }\end{array}$ & $\begin{array}{l}\text { - Combines results from both } \\
\text { quantitative and qualitative } \\
\text { sources within a review }\end{array}$ & $\begin{array}{l}\text { Can address multiple } \\
\text { questions in one } \\
\text { review }\end{array}$ & $\begin{array}{l}\text { - Requires great methodological } \\
\text { skills }\end{array}$ \\
\hline Rapid Review & $\begin{array}{l}\text { - Synthesize knowledge in a } \\
\text { quick turnaround time }\end{array}$ & $\begin{array}{l}\text { Allows for knowledge } \\
\text { synthesis in a short } \\
\text { period } \\
\text { Pragmatic uses for } \\
\text { what has been done } \\
\text { in policy or practice } \\
\text { and also new and } \\
\text { emerging research }\end{array}$ & $\begin{array}{l}\text { - Search is not as comprehensive } \\
\text { (limited amount of information } \\
\text { sources) }\end{array}$ \\
\hline
\end{tabular}

Adopted and reproduced from Ahmed et al. (2016). Conducting a literature review in health research: basics of the approach, typology, and methodology. JNHFB 2016;5(2):44-51. 
Table 3 Common types of reviews are explained using the Search, Appraisal, Synthesis, and Analysis (SALSA) framework

\begin{tabular}{|c|c|c|c|c|}
\hline \multirow{2}{*}{ Type of review } & \multicolumn{4}{|c|}{ Methods used by SALSA } \\
\hline & Search & Appraisal & Synthesis & Analysis \\
\hline $\begin{array}{l}\text { Literature Review } \\
\text { / Narrative Review } \\
\text { / Overview } \\
\text { Review }\end{array}$ & $\begin{array}{l}\text { - May or may not } \\
\text { include } \\
\text { comprehensive } \\
\text { searching }\end{array}$ & $\begin{array}{l}\text { - May or may not } \\
\text { include quality } \\
\text { assessment }\end{array}$ & $\begin{array}{l}\text { - Typically, } \\
\text { narrative }\end{array}$ & $\begin{array}{l}\text { - Analysis may be } \\
\text { chronological, } \\
\text { conceptual, thematic, etc. }\end{array}$ \\
\hline Scoping Review & $\begin{array}{l}\text { - Completeness of } \\
\text { searching } \\
\text { determined by } \\
\text { time/scope } \\
\text { constraints. May } \\
\text { include } \\
\text { research in } \\
\text { progress }\end{array}$ & $\begin{array}{l}\text { - No formal quality } \\
\text { assessment }\end{array}$ & $\begin{array}{l}\text { - Typically, tabular } \\
\text { with some } \\
\text { narrative } \\
\text { commentary }\end{array}$ & $\begin{array}{l}\text { Characterizes quantity and } \\
\text { quality } \\
\text { of literature, perhaps by } \\
\text { study } \\
\text { design and other key } \\
\text { features. } \\
\text { Attempts to specify a } \\
\text { viable review }\end{array}$ \\
\hline $\begin{array}{l}\text { Integrative } \\
\text { Review }\end{array}$ & $\begin{array}{l}\text { - Using multiple } \\
\text { search strategies } \\
\text { to conduct the } \\
\text { most exhaustive } \\
\text { search to capture } \\
\text { maximum } \\
\text { literature }\end{array}$ & - Quality assessment & - Tabular & $\begin{array}{l}\text { Identifying themes and } \\
\text { patterns through critical } \\
\text { analysis and creativity }\end{array}$ \\
\hline Critical Review & $\begin{array}{l}\text { - Seeks to identify } \\
\text { most significant } \\
\text { items } \\
\text { in the field }\end{array}$ & $\begin{array}{l}\text { - No formal quality } \\
\text { assessment. } \\
\text { Attempts } \\
\text { to evaluate } \\
\text { according } \\
\text { to contribution } \\
\end{array}$ & $\begin{array}{l}\text { - Typically, } \\
\text { narrative, } \\
\text { perhaps } \\
\text { conceptual } \\
\text { or chronological }\end{array}$ & $\begin{array}{l}\text { - Significant component: } \\
\text { seeks to } \\
\text { identify conceptual } \\
\text { contribution } \\
\text { to embody existing or } \\
\text { derive new theory }\end{array}$ \\
\hline $\begin{array}{l}\text { Systematic } \\
\text { Review }\end{array}$ & $\begin{array}{l}\text { - Aims for } \\
\text { exhaustive, } \\
\text { comprehensive } \\
\text { searching }\end{array}$ & $\begin{array}{l}\text { - Quality assessment } \\
\text { may determine } \\
\text { inclusion/exclusion }\end{array}$ & $\begin{array}{l}\text { - Typically, } \\
\text { narrative } \\
\text { with tabular } \\
\text { accompaniment }\end{array}$ & $\begin{array}{l}\text { What is known; } \\
\text { recommendations } \\
\text { for practice. What remains } \\
\text { unknown; uncertainty } \\
\text { around findings, } \\
\text { recommendations for } \\
\text { future research }\end{array}$ \\
\hline Meta-Analysis & $\begin{array}{l}\text { - Aims for } \\
\text { exhaustive, } \\
\text { comprehensive } \\
\text { searching. } \\
\text { May use funnel } \\
\text { plot to assess } \\
\text { completeness } \\
\end{array}$ & $\begin{array}{l}\text { - Quality assessment } \\
\text { may determine } \\
\text { inclusion/ } \\
\text { exclusion and/or } \\
\text { sensitivity analyses }\end{array}$ & $\begin{array}{l}\text { - Graphical and } \\
\text { tabular with } \\
\text { narrative } \\
\text { commentary }\end{array}$ & $\begin{array}{l}\text { - Numerical analysis of } \\
\text { measures } \\
\text { of effect assuming } \\
\text { absence of } \\
\text { heterogeneity }\end{array}$ \\
\hline Mapping Review & $\begin{array}{l}\text { - Completeness } \\
\text { of searching } \\
\text { determined } \\
\text { by time/scope } \\
\text { constraints }\end{array}$ & $\begin{array}{l}\text { - No formal quality } \\
\text { assessment }\end{array}$ & $\begin{array}{l}\text { - May be graphical } \\
\text { and tabular }\end{array}$ & $\begin{array}{l}\text { Characterizes quantity and } \\
\text { quality of literature, } \\
\text { perhaps by study design } \\
\text { and other keys features. } \\
\text { May identify a need for } \\
\text { primary or secondary } \\
\text { research }\end{array}$ \\
\hline $\begin{array}{l}\text { Qualitative } \\
\text { Systematic } \\
\text { Review }\end{array}$ & $\begin{array}{l}\text { - May employ } \\
\text { selective } \\
\text { or purposive } \\
\text { sampling }\end{array}$ & $\begin{array}{l}\text { Q Quality assessment } \\
\text { typically used to } \\
\text { mediate messages } \\
\text { not for inclusion / } \\
\text { exclusion }\end{array}$ & $\begin{array}{l}\text { - Qualitative, } \\
\text { narrative } \\
\text { synthesis }\end{array}$ & $\begin{array}{l}\text { Thematic analysis, may } \\
\text { include conceptual } \\
\text { models }\end{array}$ \\
\hline
\end{tabular}




\begin{tabular}{|c|c|c|c|c|}
\hline Meta-synthesis & $\begin{array}{l}\text { - Aims for rigorous, } \\
\text { systematic search } \\
\text { of relevant studies }\end{array}$ & $\begin{array}{l}\text { - Quality assessment } \\
\text { may determine } \\
\text { inclusion/exclusion } \\
\text { and/or relevance }\end{array}$ & $\begin{array}{l}\text { May involve } \\
\text { narrative } \\
\text { commentary } \\
\text { with tabular } \\
\text { and graphical } \\
\text { representation }\end{array}$ & $\begin{array}{l}\text { Interpret and transform } \\
\text { findings from multiple } \\
\text { qualitative studies to } \\
\text { reflect the explanation of } \\
\text { the phenomena }\end{array}$ \\
\hline Realist Review & $\begin{array}{l}\text { - Formal Systematic } \\
\text { search }\end{array}$ & $\begin{array}{l}\text { - Assessment of } \\
\text { relevance and } \\
\text { rigour }\end{array}$ & $\begin{array}{l}\text { - Typically, } \\
\text { tabular with } \\
\text { some narrative } \\
\text { commentary }\end{array}$ & $\begin{array}{l}\text { Identify the attributes } \\
\text { of 'what works, how, } \\
\text { for whom, in what } \\
\text { circumstances and to what } \\
\text { extent for any intervention }\end{array}$ \\
\hline $\begin{array}{l}\text { Review of Reviews } \\
\text { / Umbrella } \\
\text { Reviews }\end{array}$ & $\begin{array}{l}\text { - Identification } \\
\text { of component } \\
\text { reviews, but not } \\
\text { primary studies }\end{array}$ & $\begin{array}{l}\text { - Quality assessment } \\
\text { of studies within } \\
\text { component reviews }\end{array}$ & $\begin{array}{l}\text { - Graphical and } \\
\text { tabular with } \\
\text { some narrative } \\
\text { commentary }\end{array}$ & $\begin{array}{l}\text { What is the known } \\
\text { recommendation for } \\
\text { practice } \\
\text { What remains unknown; } \\
\text { recommendation for } \\
\text { future research }\end{array}$ \\
\hline $\begin{array}{l}\text { Mixed Methods } \\
\text { Review / Mixed } \\
\text { Studies Review }\end{array}$ & $\begin{array}{l}\text { - Distinct searches } \\
\text { for qualitative } \\
\text { and quantitative } \\
\text { literature }\end{array}$ & $\begin{array}{l}\text { - Generic assessment } \\
\text { tools/individual } \\
\text { assessment } \\
\text { processes }\end{array}$ & $\begin{array}{l}\text { - Graphical, } \\
\text { narrative, and } \\
\text { tabular }\end{array}$ & $\begin{array}{l}\text { - What correlations exist } \\
\text { between characteristics } \\
\text { - Identify gaps in the } \\
\text { information }\end{array}$ \\
\hline Rapid Review & \begin{tabular}{|l} 
- \\
Limited \\
systematic search \\
as time allows
\end{tabular} & $\begin{array}{l}\text { - Uses systematic } \\
\text { review methods } \\
\text { to critically assess } \\
\text { literature as time } \\
\text { allows }\end{array}$ & $\begin{array}{l}\text { - Narrative and } \\
\text { tabular }\end{array}$ & $\begin{array}{l}\text { What is known about a } \\
\text { specific topic } \\
\text { - Looks primarily at the } \\
\text { quantity of research } \\
\text { and overall direction of } \\
\text { research }\end{array}$ \\
\hline
\end{tabular}

Adopted and reproduced from The details of The Search, Appraisal, Synthesis, and Analysis (SALSA) framework presented with permission from John Wiley and Sons from the following reference: Grant MJ, Booth A. A typology of reviews: an analysis of 14 review types and associated methodologies. Health Information \& Libraries Journal. 2009;26(2):91-108.

\section{Depth of Synthesis}

There is one point that we would like to bring forward for the readers. The depth or intensity of synthesis, desired by the researchers, is one aspect regarding the types of reviews (Whittemore et al., 2014). In some instances, the researchers might not need to go deep into a topic, rather they may simply want to understand the current research landscape of the topic (Samnani et al., 2017). In this case, choosing a scoping review will be sufficient for their purpose (Lockwood et al., 2019). On the other hand, researchers might want to understand in-depth how exposure is related to an outcome. In this case, the researchers will need to conduct a meta-analysis level review, which requires a more rigorous methodology (Chowdhury \& Turin, 2019). Figure 3 provides a conceptual framework regarding the depth of analysis and different types of reviews. 


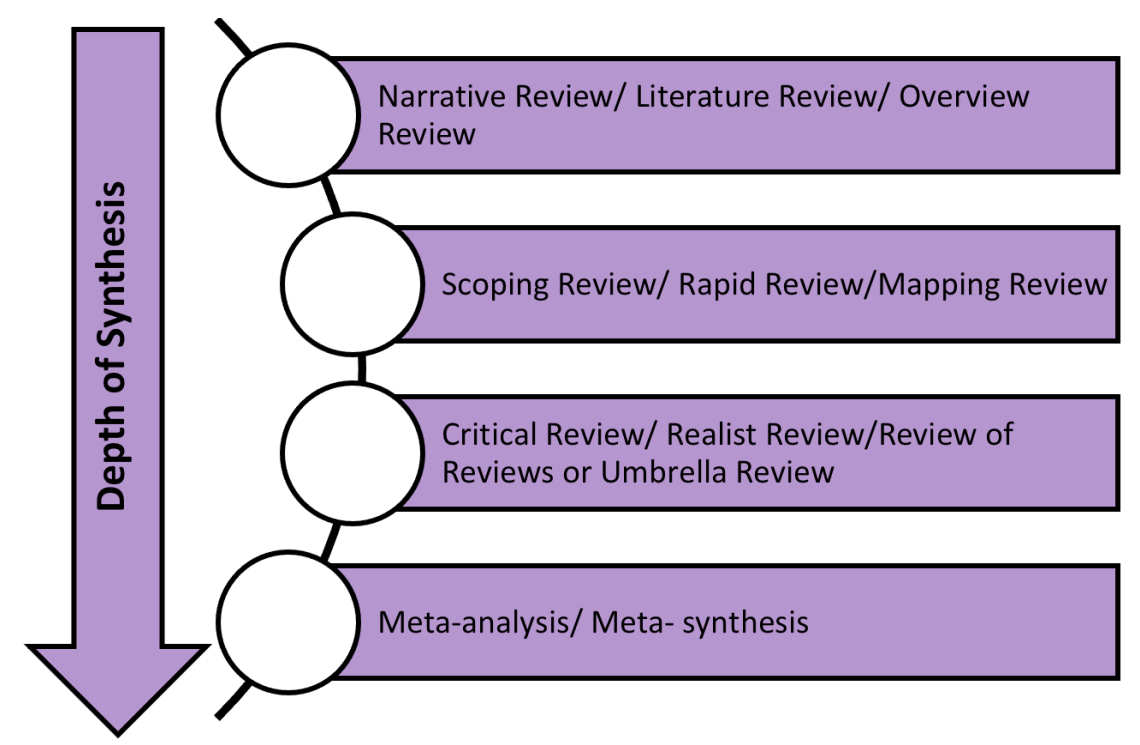

Figure 3 Depth of synthesis and review types

\section{Precision and Confidence of Synthesized Results}

It is quite natural that the more in-depth the analysis is, the more the precision of the results will be. So, in one sense, the type of review is also associated with the levels of the rigour of the results synthesized (Samnani et al., 2017). Also, we need to recognize that, in lots of instances we do not need to aspire for precision. For example, a scoping review to summarize health care access barriers faced by the racialized communities does not require in-depth analysis toward precision. On the other hand, a meta-analysis to summarise the effect of early childhood traumatic events on mental health outcomes during adulthood will need rigorous analysis. Also, we need to acknowledge that the more rigour we would like to achieve, the more time, resources, skill sets will come into play while conducting reviews (Whittemore et al., 2014). For example, a scoping review can be done in a relatively shorter time than a meta-analysis. Also, a scoping review does not warrant as many high analytical skill sets as a meta-analysis. Figure 4 provides a conceptual framework regarding the precision-confidence of results, time-resource-skill needs, and review types.

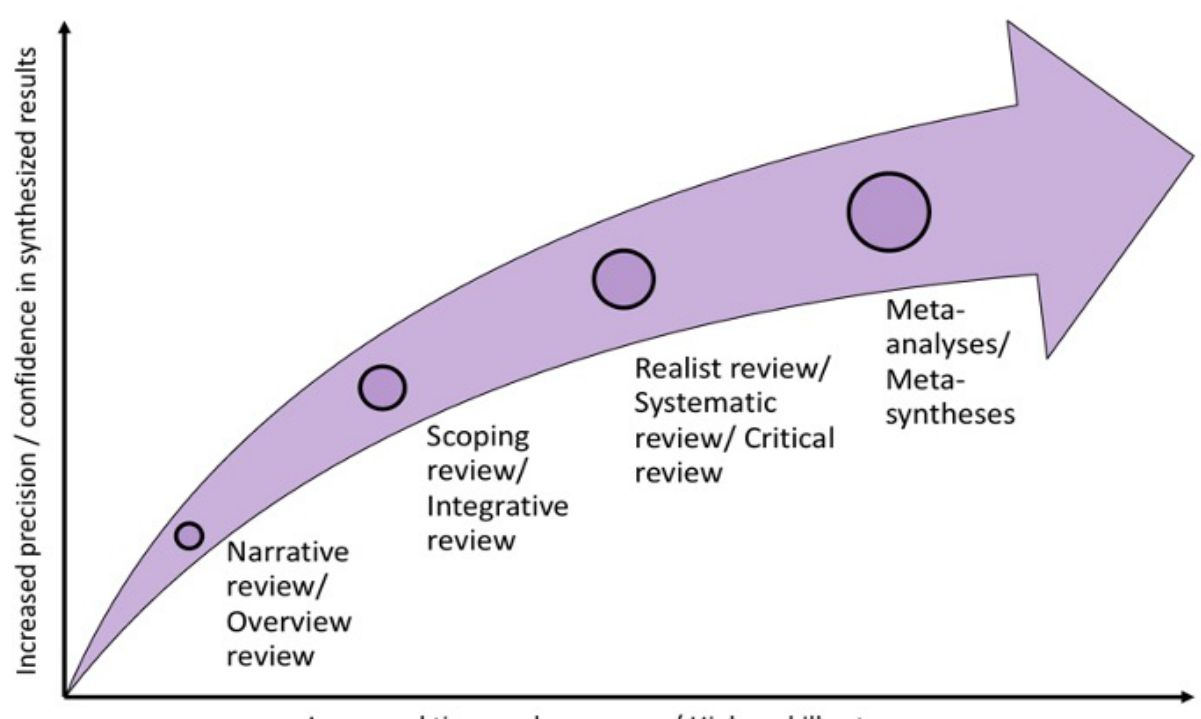

Increased time and resources / Higher skill set

Figure 4 Precision and confidence of results, time-resource-skill needs, and review types 


\section{Writing a Review Manuscript}

In an academic environment, the conventional final step in conducting a review is to prepare and publish a manuscript. The manuscript acts as a final product of the knowledge synthesis as it can be submitted to journals for publication and therefore contribute to the total body of research that has been done on the specific topic. A review manuscript generally consists of several components and Figure 5 outlines a skeleton of different components of a review manuscript.

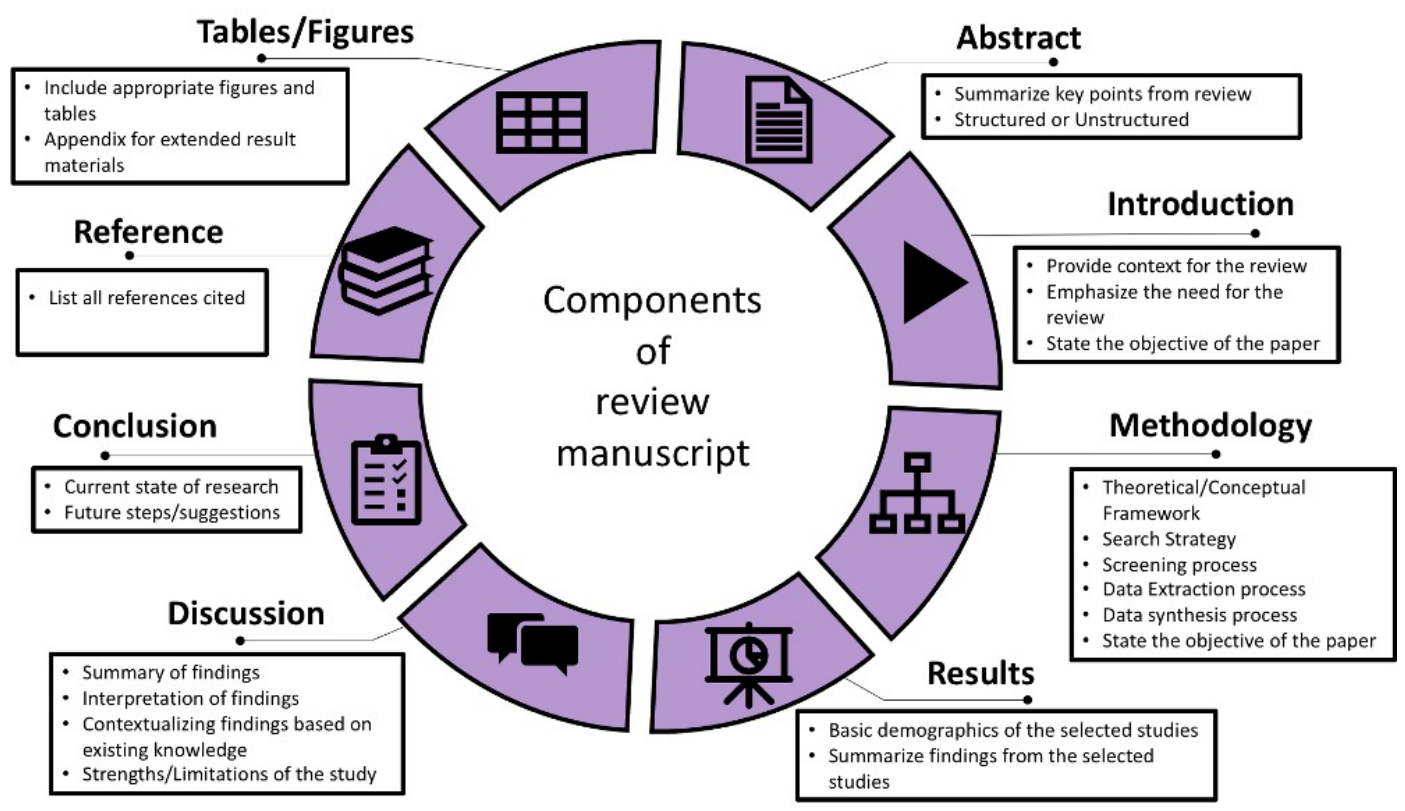

Figure 5 Components of a review manuscript

\section{PRISMA Statement}

The Preferred Reporting Items for Systematic reviews and Meta-Analyses (PRISMA) statement is a combination of a checklist and a flow diagram that standardizes the reporting of reviews so that all the necessary steps are transparent, complete, and accurate (Page et al., 2021). This helps the authors to report about why the review was done, what they did, and what they found consistently. Using the PRISMA checklist and flow diagram ensures the methodological quality of the review, allows readers to assess strengths and weaknesses, and permits replication of review methods (Guelph-Humber Library Services, 2021). Nowadays a lot of journals require the researchers to complete a PRISMA checklist and flow diagram when they submit their reviews for publication. For different types of reviews, there are different versions of PRISMA checklists (Sarkis-Onofre et al., 2021). But the flow diagram is similar to all types of reviews (Page et al., 2021). The flow diagram depicts the flow of search and screening through the different phases of a review. It maps out the number of records identified, included, and excluded, and the reasons for exclusions. A sample flow diagram is shown in Figure 6. 


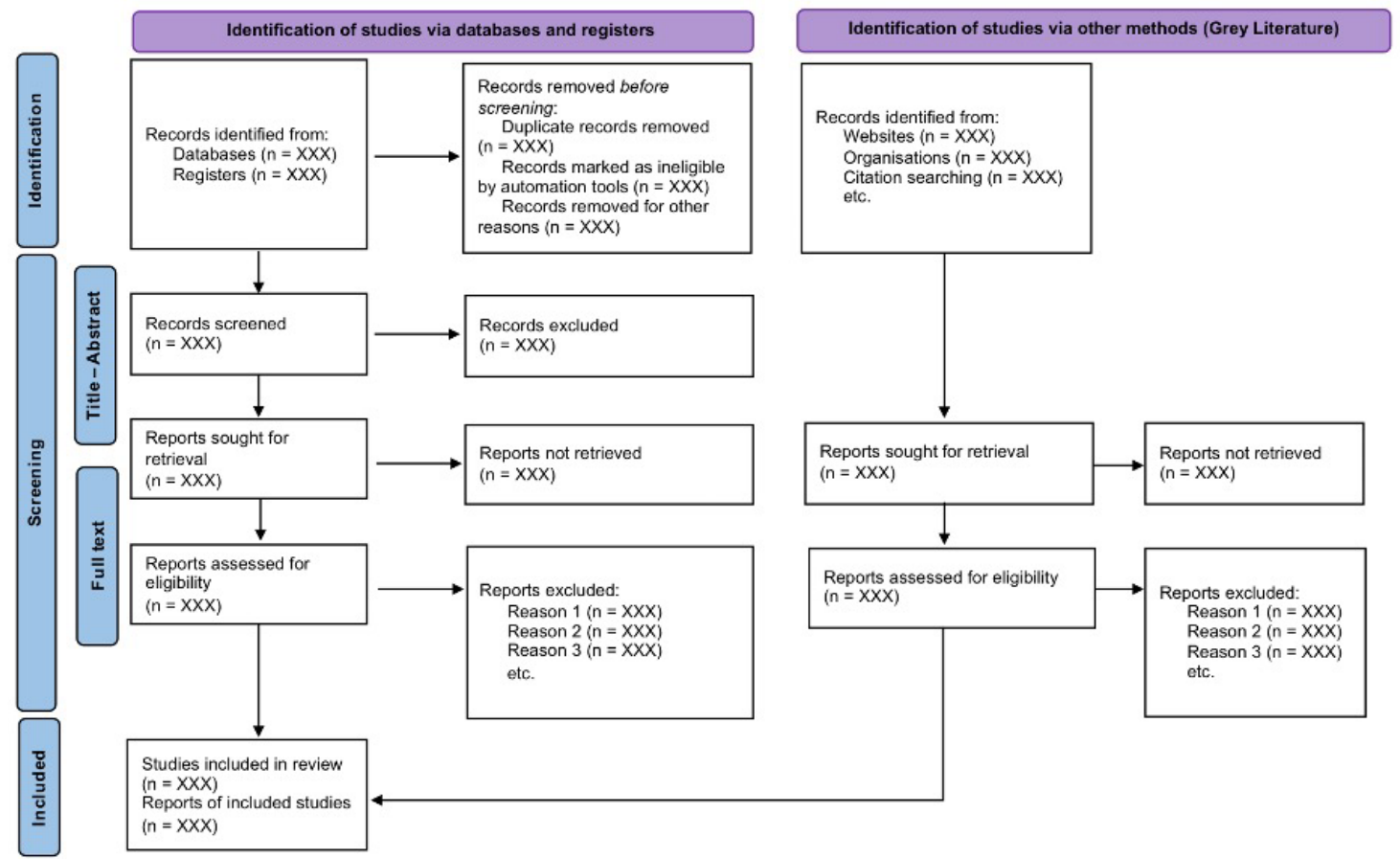

Figure 6 A sample of a flow diagram showing the components of records identified, included, and excluded, and the reasons for exclusions, finally selected paper numbers

\section{Review Team: Roles and Responsibilities}

A successful review requires a team that has variable skill sets that are necessary for the review to come to fruition. Therefore, investigators need to assemble a team that can efficiently handle the different demands of conducting a review article. Minimally, at least two investigators with proficiency in knowledge synthesis methodology and the ability to direct content are needed in the review team. Moreover, a librarian is a useful member that can be added to this team to conduct the comprehensive and expansive systematic search. The team is also responsible for dictating the scope of capture (breadth and depth) of information for the knowledge synthesis and also the potential strengths and limitations of the paper. Figure 7 illustrates these roles and responsibilities.
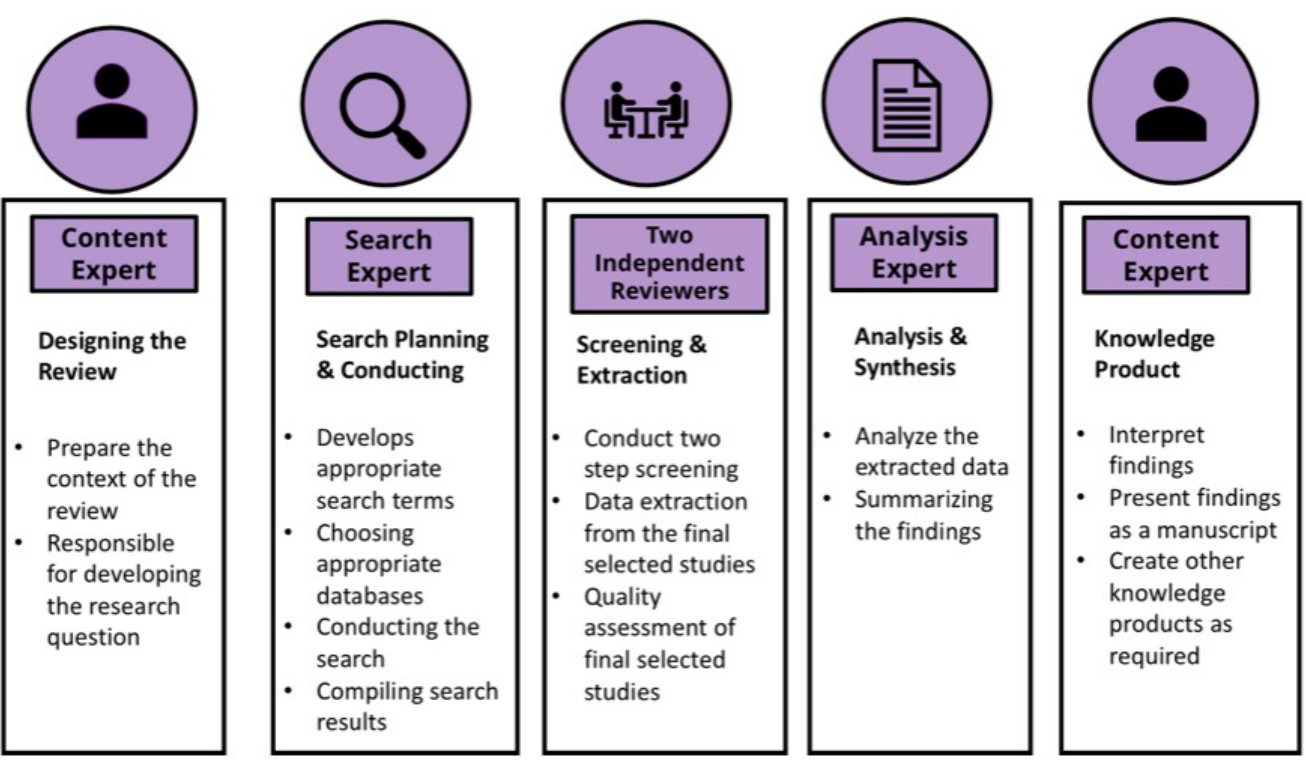

Figure 7 Review team: roles and responsibilities 


\section{Software for Assisting Reviews}

Conducting reviews in a lot of instances has become a huge undertaking. The sheer number of articles to screen, keeping track of the two-person screening, or keeping notes of several articles identified and processed from different sources - all need careful execution and recording. There are some software or applications which make the management of conducting reviews easier. Some of them are commercial and some of them are opensourced, which come with limited capabilities. For example, COVIDENCE is software that requires a paid subscription (https://www. covidence.org/). Also, Rayyan is a software and it offers free service (https://www.rayyan. ai/). This software has the potential to reduce the time and effort needed to conduct a literature review drastically by streamlining the review process and through automated documentation.

\section{CONCLUSION}

In this manuscript, we summarized a review conducting process and discussed different types of reviews that can be undertaken to fulfil knowledge synthesis requirements. A review can summarise the current understanding so that we can identify the research gap. Reviews can also be used for an in-depth understanding of measures of disease burden or measures of exposure-outcome association. Developing skills for conducting the review is an important skill for any researcher, academic group, as well as institution.

\section{CONFLICT OF INTEREST}

The authors declare that they have no competing interests in publishing this article.

\section{REFERENCES}

Ahmed, S., Vaska, M., \& Turin, T. C. (2016). Comprehensive systematic search process of health literature: Hunting pearls out of the sea. Journal of National Heart Foundation of Bangladesh, 5, $12-16$.

Bramer, W. M., Jonge, G. B. de, Rethlefsen, M. L., Mast, F., \& Kleijnen, J. (2018). A systematic approach to searching: an efficient and complete method to develop literature searches. Journal of the Medical Library Association: JMLA, 106 (4), 531. https://doi. org/10.5195/JMLA.2018.283

Canadian Agency for Drugs and Technologies in Health (CADTH). (2018). Grey Matters: A practical tool for searching health-related grey literature. CADTH. https://www.cadth.ca/ resources/finding-evidence/grey-matters

Chowdhury, M. Z. I., \& Turin, T. C. (2019). Synthesizing quantitative and qualitative studies in systematic reviews: The basics of meta-analysis and meta-synthesis. Journal of National Heart Foundation of Bangladesh, $8(2), 55-61$.

Grant, M. J., \& Booth, A. (2009). A typology of reviews: An analysis of 14 review types and associated methodologies. Health Information \& Libraries Journal, 26 (2), 91 - 108. https://doi.org/10.1111/j.14711842.2009.00848.x

Grimshaw, J. (2010). A guide to knowledge synthesis. https://cihr-irsc.gc.ca/e/41382.html

Guelph-Humber Library Services. (2021). Research guides: Systematic Reviews: PRISMA Diagram \& Checklist. https://guelphhumber.libguides. com/c.php?g=213266\&p=1406923

Icahn School of Medicine at Mount Sinai. (2020). Web of Science: Using a citation database: Pearl growing/citation mining and related records. https://libguides.mssm.edu/c. php?g=168555\&p=1107625

Kastner, M., Tricco, A. C., Soobiah, C., Lillie, E., Perrier, L., Horsley, T., Welch, V., Cogo, E., Antony, J., \& Straus, S. E. (2012). What is the most appropriate knowledge synthesis method to conduct a review? Protocol for a scoping review. BMC Medical Research Methodology, 12 (1), 1-10. https://doi.org/10.1186/14712288-12-114 
Lefebvre, C., Glanville, J., Briscoe, S., Littlewood, A., Marshall, C., Metzendorf, M. I., Noel-Storr, A., Rader, T., Shokraneh, F., Thomas, J., \& Wieland, L. S. (2019). Chapter 4: Searching for and selecting studies | Cochrane Training. Cochrane Handbook for Systematic Reviews of Interventions Version 6.0 (Updated July 2019). https://training.cochrane.org/ handbook/current/chapter-04, https://doi. org/10.1002/9781119536604.ch4

Lockwood, C., dos Santos, K. B., \& Pap, R. (2019). Practical Guidance for Knowledge Synthesis: Scoping Review Methods. Asian Nursing Research, 13 (5), 287 - 294. https://doi. org/10.1016/J.ANR.2019.11.002

McKenzie, J. E., \& Brennan, S. E. (n. d.). Chapter 12: Synthesizing and presenting findings using other methods | Cochrane Training. https:// training.cochrane.org/handbook/current/ chapter-12

Methley, A. M., Campbell, S., Chew-Graham, C., McNally, R., \& Cheraghi-Sohi, S. (2014). PICO, PICOS and SPIDER: A comparison study of specificity and sensitivity in three search tools for qualitative systematic reviews. BMC Health Services Research, 14 (1). https://doi. org/10.1186/s12913-014-0579-0

Page, M. J., McKenzie, J. E., Bossuyt, P. M., Boutron, I., Hoffmann, T. C., Mulrow, C. D., Shamseer, L., Tetzlaff, J. M., Akl, E. A., Brennan, S. E., Chou, R., Glanville, J., Grimshaw, J. M., Hróbjartsson, A., Lalu, M. M., Li, T., Loder, E. W., Mayo-Wilson, E., McDonald, S., McGuinness, L. A., Stewart, L. A., ... Moher, D. (2021). The PRISMA 2020 statement: An updated guideline for reporting systematic reviews. The $B M J, 372$, 71. https://doi.org/10.1136/bmj.n71

Samnani, S. S., Vaska, M., Ahmed, S., \& Turin, T. C. (2017). Review Typology: The Basic Types of Reviews for Synthesizing Evidence for the Purpose of Knowledge Translation. Journal of the College of Physicians and Surgeons-Pakistan, 27 (10), 635 - 641. https://doi. org/2724

Sarkis-Onofre, R., Catalá-López, F., Aromataris, E., \& Lockwood, C. (2021). How to properly use the PRISMA Statement. Systematic Reviews, 10 (1), 1 - 3. https://doi.org/10.1186/s13643021-01671-z
Schardt, C., Adams, M. B., Owens, T., Keitz, S., \& Fontelo, P. (2007). Utilization of the PICO framework to improve searching PubMed for clinical questions. BMC Medical Informatics and Decision Making, 7 (1), 1 - 6. https://doi. org/10.1186/1472-6947-7-16

Schöpfel, J., \& Farace, D. J. (2010). Grey literature. In M. J. Bates \& M. N. Maack (Eds.), Encyclopedia of library and information sciences (3rd ed., 2029 - 2039). CRC Press. https://doi. org/10.1201/9780203757635

Shepherd, J., Dewhirst, S., Pickett, K., Byrne, J., Speller, V., Grace, M., Almond, P., Hartwell, D., \& Roderick, P. (2013). Factors facilitating and constraining the delivery of effective teacher training to promote health and well-being in schools: A survey of current practice and systematic review. Public Health Research, 1 (2), 1 - 188. https://doi.org/10.3310/ phr01020

Tricco, A. C., Lillie, E., Zarin, W., O'Brien, K. K., Colquhoun, H., Levac, D., Moher, D., Peters, M. D. J., Horsley, T., Weeks, L., Hempel, S., Akl, E. A., Chang, C., McGowan, J., Stewart, L., Hartling, L., Aldcroft, A., Wilson, $M$. G., Garritty, C., Lewin, S., Godfrey, C. M., Macdonald, M. T., Langlois, E. V., SoaresWeiser, K., Moriarty, J., Clifford, T., Tunçalp, Ö., \& Straus, S. E. (2018). PRISMA extension for scoping reviews (PRISMA-ScR): Checklist and explanation. Annals of Internal Medicine, 169 (7), 467 - 473. https://doi.org/10.7326/ M18-0850

U.S. National Library of Medicine. (2012). Introduction: What is MeSH? U.S. National Library of Medicine. https://www.nlm.nih. gov/bsd/disted/meshtutorial/introduction/

University of Tasmania. (2021). Systematic Reviews for Health - Building Search Strategies [Library guide]. https://utas.libguides.com/ SystematicReviews/SearchStrategies

Vaska, M., Chowdhury, M., Naidu, J., Baig, K., \& Turin, T. (2019). Exploring all that is grey in the health sciences: What is grey literature and how to use it for comprehensive knowledge synthesis. Journal of National Heart Foundation of Bangladesh, 8 (1), 14 - 19.

Whittemore, R., Chao, A., Jang, M., Minges, K. E., \& Park, C. (2014). Methods for knowledge synthesis: An overview. Heart \& Lung, 43 (5), 453 - 461. https://doi.org/10.1016/J. HRTLNG.2014.05.014 